\title{
Effects of Planting Depth on Germination and Growth of Faba Bean (Vicia faba L.) at Fitche, Oromia National Regional State, Central Ethiopia
}

\author{
Endalkachew Baye*, Zebiba Ebirahim, Naol Kasahun, Nebiyat Wasyihun, Kebede Siyum, \\ Dinknesh Yachiso, Zenash Tiruneh, Bosena Fekadu
}

Department of Plant Sciences, College of Agriculture and Natural Resource, Salale University, Fitch, Ethiopia

Email address:

bayeendalkachew4@gmail.com (E. Baye)

\section{To cite this article:}

Endalkachew Baye, Zebiba Ebirahim, Naol Kasahun, Nebiyat Wasyihun, Kebede Siyum, Dinknesh Yachiso, Zenash Tiruneh, Bosena Fekadu. Effects of Planting Depth on Germination and Growth of Faba Bean (Vicia faba L.) at Fitche, Oromia National Regional State, Central Ethiopia. American Journal of Agriculture and Forestry. Vol. 8, No. 3, 2020, pp. 58-63. doi: 10.11648/j.ajaf.20200803.11

Received: February 3, 2020; Accepted: April 13, 2020; Published: May 28, 2020

\begin{abstract}
The depth of sowing is important in maximizing the potential of seedling emergence and crop growth. Too shallow sowing results in poor germination due to inadequate soil moisture at the top soil layer. On the other hand, deep sowing can also significantly reduce crop emergence and growth. It would create the emergence seedling had less performance and productive which means when it is too deep is not able lift its cotyledon above the soil, soil born diseases and insects have damage their seedling. These factors limit the crop yield potential right from the starting of the growing. An important objective of seeding for improved crop performance is putting seeds at a desired depth. Seeds should be sown at a depth that increases the likelihood of germination, emergence and improved growth. Thus, this study examined the effect of different sowing depths on germination and growth faba bean (Gorra variety) at Fitche, central Ethiopia. A randomized complete block design arrangement with three replications was used for the experiment. The treatments consisted of 4, 6, 8, 10 and $12 \mathrm{~cm}$ sowing depths. Analysis of variance showed significant effect of depth of sowing on Gorra faba bean variety germination and growth. Sowing at a depth of $8 \mathrm{~cm}$ showed better germination percentage, fast emergence and produced the tallest plant having the highest number of leaves per plant. $12 \mathrm{~cm}$ sowing depth (i.e. the deepest sowing depth) showed poor germination percentage (65.7\%), late emergence (7 days) and gave the shortest plant $(13.53 \mathrm{~cm})$ with the lowest number of leaves per plant $(21)$. Therefore, better germination, emergence and improved growth, Gorra faba bean variety should be sown at a depth of $8 \mathrm{~cm}$.
\end{abstract}

Keywords: Faba Bean, Germination, Gorra, Growth, Sowing Depth

\section{Introduction}

Faba bean (Vicia faba L., $2 \mathrm{n}=12$ ), is a legume member belonging to the family of Fabaceae. $[14,13]$. It is assigned to the Central Asian, Mediterranean, and South American centers of diversity and believed to be a native to North Africa and southwest Asia, and extensively cultivated elsewhere [32]. [7] postulated a Near Eastern center of origin, with four extents to Europe along the North African coast to Spain, along the Nile to Ethiopia, and from Mesopotamia to India. Secondary centers of diversity are postulated in Afghanistan and Ethiopia. However, [12] reported the origin to be Central Asia. The crop is known by many names, most of which refer to a particular subgroup rather than the whole species [16]. Faba bean, Fava bean, Broad bean, Horse bean, Windsor bean, Tick beans (small types), Bakela (Ethiopia), Boby kurmouvje (former USSR), Faveira (Portugal), Ful masri (Sudan), Feve (French) and Yeshil Bakla (Turkey) are the few names used in different parts of world [20; 24]. Field beans are plants which are widely used all around the world. It is the third most important leguminous plant after soybeans (Glycine max L.) and peas (Pisum sativum L.) [26].

Presently, faba beans are major crop in many countries including China, Ethiopia and Egypt, and are widely grown for human food throughout the Mediterranean region and in parts of Latin America [21]. China is major shareholder in production with $60 \%$ [10]. World average of faba bean 
productivity is $1.5 \mathrm{t} / \mathrm{ha}$ and African average productivity is 1.3t/ha, Egypt ranked first with $2.96 \mathrm{t} /$ ha [9]. Ethiopia is the second largest faba bean producer in the world next to China and accounts for about $12 \%$ of the world area and production with an average yield of $1.1 \mathrm{t} \mathrm{ha}^{-1}$ [6].

Faba bean has a great potential to be used as a source of nutrition for human food and as a N2-fixing legume play an essential role in enhancing soil fertility [8]. With this the crop has been cultivated almost in 58 countries of the world [10]. It is a valuable food legume which is rich in proteins and carbohydrates for peoples of Middle East and North Africa [28]. It is also a rich source of lysine rich protein (20-30\%) depending upon cultivars and agroclimatic conditions under which faba bean grown. They are also fairly high in 13carotene. thiamine, riboflavin, iron and good source of dietary fiber. Seeds are roasted and eaten like groundnut, eaten as vegetable and also grown for fodder and hay purpose [25]. It has been considered as a meat extender or substitute and as a skim- milk substitute. Straw from faba bean harvest fetches a premium in Egypt and Sudan and is considered as a cash crop. The straw can also be used for brick making and as a fuel in parts of Sudan and Ethiopia [28]. It also p plays a significant role for Ethiopian farmers as a source of food, feed and cash crop [11]. It also plays a great role as cash crop, important sources of dietary protein and they correct important amino acid deficiencies and also improves soil fertility [2] It is the most important cool-season food legume in Ethiopia in terms of coverage, production, foreign exchange earnings, protein source, soil amelioration and cropping system [27].

Even though the crop plays a significant role for Ethiopian farmers as a source of food, feed and cash crop, the yield is low $\left(1.1 \mathrm{t} \mathrm{ha}^{-1}\right)$ compared with the world $(1.5 \mathrm{t} / \mathrm{ha})$ average [6]. This is due to several factors like poor crop management practices, lack of high yielding cultivars, stress inflicted by harsh environmental conditions, diseases, poor soil fertility and improper agronomic practice viz. sowing depth, plant density [11]. But with good agronomic practice and by using improved varieties, the yield can reach up to $4 \mathrm{tha}^{-1}$ [5].

Sowing depth greatly influences crops ability to emerge and establish a uniform stand [17]. Because, time taken by plant to germinate is governed by depth of seeding, size of seed viz. reserve food material [24]. Successful germination is based on size of seed (reserve food material) and length of plumose and coleoptiles of particular crops. Therefore, it is important to plant accurately in order to achieve good germination, emergence and high plant population
(Alghamdi, 2002). The depth of sowing is important in maximizing the potential of seedling emergence and crop yield. Too shallow sowing results in poor germination due to inadequate soil moisture at the top soil layer. On the other hand, deep sowing can also significantly reduce crop emergence and yield [4]. It would create seedlings that had less performance and productive which means when it is too deep seeds cannot able lift its cotyledon above the soil, then soil born diseases and insects have damage their seedling or too shallow depth they wilt due to lack of moisture from the upper soil surface. These factors limit the crop yield potential right from the starting of the germination. In order to optimize the production potential of legume crops, an experimental trail should be conducted to ascertain the role of establishment methods, planting geometry and seeding depths to optimize faba bean productivity [17].

The main objective of seeding is to put seeds at a desired depth and spacing within the row. Uniform seed spacing and depth result in better germination and emergence and increase yield by minimizing competition between plants for available light, water, and nutrients [18]. Information about sowing depth effects on Gorra faba bean variety germination and growth is scanty. Thus, the objective of the study was to compare the effect of different sowing depths on germination and growth and to identify the optimum planting depth Gorra variety.

\section{Materials and Methods}

\subsection{Description of the Study Area}

Field experiment was conducted at Salale University General Tadesse Biru Campus, Plant Science Demonstration Site during 2019 cropping season. The University is found in Fitche town, North Shewa Zone of Oromia Region at $113 \mathrm{~km}$ away from Addis Ababa in Northern direction on the way to Gojjam. It is located at $9^{0} 48^{\prime} 0^{\prime} \mathrm{N}$ latitude and $38^{\circ} 42^{\prime}{ }^{\prime} 0$ ' longitude. The altitude of the area is 2750 m.a.s.1. The average temperature and annual rainfall of an area is 16.50 and $1150 \mathrm{~mm} /$ year, respectively. The soil type is clay (Verti soil) with $\mathrm{pH}$ of 6.4 (Abera et al., 2013).

\subsection{Description of Planting Material}

Faba bean variety namely Gorra was used for the field experiment. The seeds of the cultivar were collected from Holeta Agricultural Research Center (HARC).

Table 1. Description of planting Material.

\begin{tabular}{llllllll}
\hline $\begin{array}{l}\text { Name of } \\
\text { Variety }\end{array}$ & $\begin{array}{l}\text { Year of } \\
\text { release }\end{array}$ & $\begin{array}{l}\text { Days to } \\
\text { maturity }\end{array}$ & $\begin{array}{l}\mathbf{1 0 0 0} \text { seed } \\
\text { weight } \mathbf{( g m )}\end{array}$ & $\begin{array}{l}\text { Flower } \\
\text { Color }\end{array}$ & \multirow{2}{*}{ Seed color } & \multicolumn{2}{c}{ Yield (q/ha) } \\
\cline { 6 - 8 } & On Station & On farm \\
\hline Gorra & 2013 & $126-168$ & 938 & White by black & Light green & $22-57$ & $20-40$ \\
\hline
\end{tabular}

Source: EIAR, 2018

\subsection{Experimental Design and Treatments}

The field experiment was laid out in randomized complete block design (RCBD) with three replications. The treatment used for the experiment were five different sowing depths i.e. $4,6,8,10$ and $12 \mathrm{~cm}$. The size of a unit plot used for the field experiment was $4 \mathrm{~m}^{2}$ ( $2 \mathrm{~m}$ length $\mathrm{x} 2 \mathrm{~m}$ width). Each of the 
plots were consisting of five rows, with intra and inter row spacing of $10 \mathrm{~cm}$ and $40 \mathrm{~cm}$ respectively. The space between plots and blocks were $0.5 \mathrm{~m}$ and $1 \mathrm{~m}$ respectively. The total experimental are used for the field experiment was $12 * 8=96 \mathrm{~m}^{2}$. Two seeds were sown per the prepared planting whole with these 200 seed were sown per each plot and a total 3,000 seeds per experiment were used.

Table 2. The treatments used.

\begin{tabular}{ll}
\hline Treatments & Depth (cm) \\
\hline Treatment one (T1) & 4 \\
Treatment two (T2) & 6 \\
Treatment three (T3) & 8 \\
Treatment four (T4) & 10 \\
Treatment five (T5) & 12 \\
\hline
\end{tabular}

\subsection{Experimental Procedures and Agronomic Practices}

The experimental field was managed as per the standard field plot techniques and standard agronomic practice.

Land preparation: The experimental field was selected and all unwanted material like rubbish, stone, wood, straw, weed and other substances were removed. Before the layout of the experiment the field was ploughed using oxen to a depth of $25-30 \mathrm{~cm}$, disked and harrowed with human labor to make fine tilth and experimental plots will be prepared based on the pre-determined design; then ridges will be made by hand.

Planting: Two healthy seeds of Gora faba bean variety were planted per wholes prepared based on the pre assigned treatment to guarantee the germination of the seeds.

Fertilizer application: Urea and DAP fertilizer were used as source of nitrogen and phosphorous respectively. The recommended rates of DAP and urea are 100 and $50 \mathrm{~kg} \mathrm{ha}^{-1}$ respectively (MoANR, 1993-2014). The whole rate of DAP was applied at the time of planting while nitrogen fertilizer was applied in the form of Urea in two splits, $1 / 2$ during planting and $1 / 2$ at the initiation of tillers. Even though, the crop is nitrogen fixer in nature, starter dose of nitrogen fertilizer (Urea) $(50 \mathrm{~kg} / \mathrm{ha})$ was added to initiate nodulation process.

Crop protection: plants were treated with Mancozeb $80 \%$ at the rate of $1.5 \mathrm{~kg} \mathrm{ha}^{-1}$ diluted at the rate of $40 \mathrm{~g}$ per 20 litter water once a week to control chocolate leaf spot.

All other management practices such as watering, weeding and pest control were done uniformly for all plots. Urea and DAP fertilizer will be used as source of nitrogen and phosphorous respectively.

\subsection{Data Collected}

Days to $50 \%$ emergency: is the number of days taken by $50 \%$ the seeds per plot to emerge. It was recorded by counting the number of days starting from sowing to the day that $50 \%$ the seeds sown took to emerge in day and the average was taken.

Germination percentage (\%): it is the ratio of seeds giving germination to the total number of seeds sown per each plot. It was recorded by counting the number of germinated seeds per and dividing by the total number of seeds sown per each plot and multiplied by 100 and the average was taken.

$$
\mathrm{GP}=\frac{\text { number of germinated seeds }}{\text { total number of seeds sown }} \times 100
$$

Plant height: was recorded by measuring the height of five randomly selected plants from the three central rows by a ruler from the surface of the ground to the tip of the main stem at $50 \%$ flowering and the average was taken.

Number of leaves: was recorded by counting the number of leaves of five randomly selected plants from the middle three rows for each plot and the average were taken.

\subsection{Data Analysis}

The collected data were subjected to analysis of variance (ANOVA) for RCBD; using SAS 9.3 and the significance level were evaluated using least significance difference (LSD) at 5\% probability level as outline by Gomez and Gomez (1984).

\section{Result and Discussion}

\subsection{Days to $50 \%$ Emergence}

The analysis of variance (ANOVA) showed that there was a significant difference in date of 50\% emergence among the various sowing depth at $p>0.05$. Early emergency ( 7 days) was recorded from seeds sown on plots which receive treatments with low sowing depth $(4$ and $6 \mathrm{~cm})$ while the longest day of $50 \%$ emergency (12.5 days) was obtained from treatment five sown at $12 \mathrm{~cm}$ depth (Table 3 ). The mean dates of $50 \%$ emergence increased from 7 days to 12.5 days as the sowing depth increased from $4 \mathrm{~cm}$ to $12 \mathrm{~cm}$ as shown below in table 3. This might be due to the increase in distance for the coleoptile and radicle to emmerge as the sowing depth increases. Similar result was reported by [24]. These researchers found that the time taken by a plant seed to germinate is governed by depth of seeding, size of seed (reserve food material). They also said that successful germination is based on size of seed (reserve food material) and length of plumose and coleoptiles of particular crops. According to their report the time required by the faba bean seed to germinate is dependent both the size and sowing depth. Likewise, [25] reported that each increase in depth of seeding delayed the germination time by taking more time to emerge. Similarly, [29] stated that telfairia seeds sown at $3 \mathrm{~cm}$ and $6 \mathrm{~cm}$ depths germinated faster than seeds sown at $9 \mathrm{~cm}$ and $12 \mathrm{~cm}$ depths. The delay in days to $50 \%$ germination with increase sowing depth may also due to the compaction of the soil as the depth increased and the requirement of higher energy by the coleoptile to burst the compacted soil and to emerge. In line with this [30] found that, the coleoptile (a leaf sheath that surrounds and protects the first true leaf as it grows from the seed towards the surface) increase with increase in sowing depth. The also reported that when the length of the coleoptile is less than the depth of planting, emergence will become difficult.

Treatment one having $4 \mathrm{~cm}$ depth and treatment two 
having $6 \mathrm{~cm}$ depth were germinated similarly, but treatment 2 having $6 \mathrm{~cm}$ depth differ in vigorisity of plumule and good leaf that were sprout from the soil. Treatment four having 12 $\mathrm{cm}$ depth germinated seedling were highly damaged. According to these result the optimum or moderate depth of sowing were most important for germination that leads to increase performance of seed. Thus, there is highly seedling performance of optimum sowing depth than highly depth and shallower depth, but the germination date increase in highly deeper than shallower depth respectively. Similar result was also reported by Donald and Puckingge (2014) who reported that as the depth of sowing increases the cover of the soil for the seed increases and the seedlings require more days to come out of the underground part. [24] also reported about the increment of the day taken for $50 \%$ emergency to occur as the depth of seeding increases.

\subsection{Germination Percentage \%}

There was a significant difference $(\mathrm{P}>0.05)$ between seeds with different sowing depth in terms of germination percentage. For germination percentage, the data were collected from central three rows (120 seeds/plot). The highest seeds (108) which germinated were obtained from seeds sown at $4 \mathrm{~cm}, 6 \mathrm{~cm}$ depth and at $8 \mathrm{~cm}$ were seeds. However, the number of seeds germinated at depth of $10 \mathrm{~cm}$ and $12 \mathrm{~cm}$ were 85 and 78 seedlings respectively. The germination percentage of the depth, 4,6 and $8 \mathrm{~cm}$ depth were $90.13 \%$. $90.07 \%$ and $90.33 \%$ respectively. While the germination percentage of 10 and $12 \mathrm{~cm}$ depth was $70.67 \%$ and $65.07 \%$ respectively (Table 3 ). This indicated that as sowing depth increase the number seeds to be germinated decreased. In contrary, as the sowing depth decrease the seed would have germinated fastly even if it has less performance of seedlings. According to the result of present investigation, it was observed that as increase in the planting depth germination percentage was decrease. Therefore, sowing depth can affect on the germination percentage of the faba bean. This might be due to requirement of more strength by seeds sown in deeper depth to push its shoots above the soil surface. The lower germination percentages recorded at deeper depths may be also due to the fact that the seeds buried with soil preventing the seeds from accessing optimum water, air, light and temperature, hence decrease in germination with increasing planting depths, as confirmed by [19]. Similar result was also reported by [15] who found that there was a significant different in germination percentage in faba bean when sown at different planting depth. The negative effect of deep sowing depth on germination percentage is also reported by Nabi et al. (2011) who found that seedling emergence was decreased with increased sowing depth in cotton. [3] also indicated that the number of germinated seeds was greatly reduced with the increased depth of planting, too shallow sowing results in poor germination due to inadequate soil moisture at the top soil layer, deep sowing can also significantly reduce crop emergence and yield. Similarly, [29] stated that telfairia seeds sown at $3 \mathrm{~cm}$ and $6 \mathrm{~cm}$ depths germinated faster than seeds sown at $9 \mathrm{~cm}$ and $12 \mathrm{~cm}$ depths. According to these researchers, seeds sown at $3 \mathrm{~cm}$ depths had the highest percentage of germination. Deep sowing also causes elongation of stem between the seed and secondary roots. The food reserves of the grain are taxed severely and seedling may even fail to emerge. An increase in hypocotyl or epicotyl length, as noted in deep seedling reduce the probability of the seedlings being capable of overcoming soil strength and render the seedlings more susceptible to attack by pathogens [31].

\subsection{Plant Height}

Regarding plant height, the analysis of variance showed that there was a significance difference in plant height between the treatments evaluated at $p>0$. 05. The highest plant height $(31.4 \mathrm{~cm})$ was obtained from plants raised from seeds sown at $8 \mathrm{~cm}$ depth of sowing while the lowest plant height $(13.53 \mathrm{~cm})$ was recorded from plants raised from seeds sown at the highest $(12 \mathrm{~cm})$ planting depth (Table 3$)$. The value of plant height of the present field experiment decreased with further increase in sowing depth above optimum. This might be due to the prevention of the seedlings sown at deeper depth from pushing their shoot above the thick compact soil that initially leave seeds sown at lower depth to establish faster. [3] found consistent result with the present result from soybean sown at different planting depth. These researchers reported a highest plant height at $5 \mathrm{~cm}$ depth and shortest plant height from seeds sown at the highest planting depth $(9 \mathrm{~cm})$. Higher plant height at medium sowing depths may suggest an increased cell division and enlargement, which could be probably due to high amounts of nutrients and water available at 2 and $4 \mathrm{~cm}$ depths. Growth involves both cell growth and development which is a process consisting of cell division, cell enlargement and differentiation [23]. The results indicate that medium sowing depth is optimal for higher plant height. The results are in agreement with those of [4] in Cow pea and Pesboilles (2000) for wheat. [29] found that sowing depths significantly reduced cumulative height growth over time in Telfairia occidentalis. Contradictory result to this work regarding the effect of sowing depth on plant height was reported by [4] who reported that sowing depth has no a significant different on plant height of cowpea sown on different depth.

\subsection{Number of Leaves Per Plant}

Sowing depth has a significant effect on number of leaves per plant at $p>0.5$. The highest number of leaves (44.67) per plant was recorded from plants grown from seeds sown at 8 $\mathrm{cm}$ sowing depth while the lowest number of leaves per plant (21.00) was obtained from plants raised from seeds sown at $12 \mathrm{~cm}$ planting depth which is the highest sowing depth for this field experiment (Table 3). The Number of leaves per plant declined as sowing depth increased. The reason behind this is that, seedlings raised from deeply sown seeds produced fewer amounts of leaves and this might have been 
expected as deep sowing has been shown to have a number of consequences on seedling growth. Similar result was reported by [22]. In contrary to the present result [4] reported the non-significance of number of leaves per plant in five different sowing depths.

Table 3. Effect of Sowing Depth on Germination and Growth Parameters of Gorra Variety.

\begin{tabular}{lllll}
\hline Depth (cm) & DE (day) & GP $(\%)$ & PH (cm) & LN (No.) \\
\hline 4 & $7^{\mathrm{d}}$ & $90.13^{\mathrm{a}}$ & $24.03^{\mathrm{b}}$ & $36.67^{\mathrm{b}}$ \\
6 & $7^{\mathrm{d}}$ & $90.07^{\mathrm{a}}$ & $24.30^{\mathrm{b}}$ & $38.00^{\mathrm{b}}$ \\
8 & $8^{\mathrm{c}}$ & $90.33^{\mathrm{a}}$ & $31.40^{\mathrm{a}}$ & $44.67^{\mathrm{a}}$ \\
10 & $10^{\mathrm{b}}$ & $70.67^{\mathrm{b}}$ & $17.30^{\mathrm{c}}$ & $26.00^{\mathrm{c}}$ \\
12 & $12.5^{\mathrm{a}}$ & $65.07^{\mathrm{c}}$ & $13.53^{\mathrm{d}}$ & $21.00^{\mathrm{d}}$ \\
LSD & 0.5570 & 1.760 & 0.964 & 3.972 \\
CV $(\%)$ & 3.3 & 1.2 & 2.3 & 6.3 \\
\hline
\end{tabular}

$\mathrm{LSD}=$ least significance difference, $\mathrm{CV}=$ Coefficient of Variation, $\mathrm{DE}=$ Days taken to $50 \%$

Emergence, $\mathrm{GP}=$ Germination Percentage, $\mathrm{PH}=\mathrm{Plant}$ Height, LN=Leaf Number

\section{Summary and Conclusion}

Faba bean (Vicia faba L.) is the most important crop in the world. But its productivity in the world including Ethiopia is low due to different constrains like improper agronomic practices like above or below optimum sowing depth lack of improved varieties. Selection of the correct sowing depth of sowing for any crop is important. Depth of sowing affects seedling emergence, growth and yield of crops. Uniform seeding depth is essential towards achieving higher crop yield. Proper depth is essential in order to achieve good germination, emergence and high plant population. Therefore, the main objective of this study was to determine the effect of planting depth on germination and growth of faba bean. Based on the results obtained, the following conclusion is drawn $8 \mathrm{~cm}$ sowing depth produced the highest germination percentage $(90.33 \%)$, the tallest plant height $(31.40 \mathrm{~cm})$ and highest number of leaves per plant (45). This was followed by the $6 \mathrm{~cm}, 4 \mathrm{~cm}$ and $10 \mathrm{~cm}$ and $12 \mathrm{~cm}$ sowing depths respectively. Sowing at $12 \mathrm{~cm}$ depth gave the poorest germination percentage, the shortest plant and lowest number of leaves per plant. According to this result, the optimum depth of sowing was most important for germination that leads to increase performance of seed. Thus, there is highly seedling performance of optimum sowing depth than highly deep and shallow depths. Therefore, Gorra faba bean variety should be sown at a depth of $8 \mathrm{~cm}$ to obtain the best germination and growth at Fitch location.

\section{Future Line of Work}

1. The effect of different sowing depth on growth, yield and yield component of other varieties of faba bean.

2. The effect of both sowing depth and seed size on growth, yield and yield component of different faba bean varieties.

3. The effect of sowing depth on faba bean production with consideration of the moisture content and type of the soil to be studied up on.

\section{References}

[1] Abd-Alla, M. H., El-Enany, A. E., Hamada, A. M., and Abdel Wahab, A. M. (2001). Element distribution in faba bean root nodules under salinity and its effects on growth, nodulation and nitrogen fixation. Plant Soil Environ. 47, 399-404.

[2] Abraham Tadesse, 2008. Increasing crop production through improved plant production vol. I. Addis Ababa Ethiopia.

[3] Aikins S. H. M., Afuakwa J. J. and Nkansah E. O. (2011). Effect of different sowing depths on soybean growth and dry matter yield. Agriculture and Biology Journal of North America. 2 (9): 1273-1278.

[4] Aikins, S. H. M. and Afuakwa, J. J. (2008). Growth and Dry Matter Yield Responses of Cowpea to Different Sowing Depths, ARPN Journal of Agricultural and Biological Science, 3 (5 \& 6): 50-54.

[5] CSA-Central Statistical Agency (2016/17). Agricultural Sample Survey 2012 Report on Area and Production of Major Crops for Private Peasant Holdings, Meher Season. Addis Ababa.

[6] CSA-Central Statistical Agency (2017/18). Agricultural sample survey on area and production of crops. May 2010, Addis Ababa, Ethiopia.

[7] Cubero J. I. (1974). On the evolution of Vicia faba. Theor. Appl. Genet. 45: 47-51.

[8] El-Kholy A. S. M., Aly R. M. A., A. Y. A., El-Bana and Yasin M. A. T. (2019). Yield of Faba Bean (Vicia Faba, L.) As Influenced by Planting Density, Humic Acid Rate and Phosphorus Fertilization Level Under Drip Irrigation System in Sandy Soils. Zagazig J. Agric. Res., Vol. 46 No. (6A).

[9] FAO (Food and Agricultural Organization of the United Nations) (2017). Statistical pocket book for world Food and Agriculture. Rome, Italy.

[10] FAOSTAT (2009). Production stat: crops. FAO statistical databases (FAO stat), food and agriculture organization of the United Nations (FAO), http://faostat.fao.org.

[11] Getachew, A., Asnake, F., and Ayalew, T. (2006). Cropping systems, soil fertility, and crop management research on cool season food legumes in the central highlands of Ethiopia: A review. In K. Ali (Ed.), Food and Forage Legumes of Ethiopia: Progress and Prospects (pp. 135-145). Aleppo: ICARDA.

[12] Hajjar R and Hodgkin T (2007). The use of wild relatives in crop improvement: a survey of developments over the last 20 years. Euphytica 156: 1-13.

[13] Hanelt P, Mettin D (2009). Biosystematics of the genus Vicia L. (Leguminosae). Annu. Rev. Ecol. Syst. 20: 199-223.

[14] Harlan JR (1969). Ethiopia: A center of diversity. Econ. Bot. 23: 309-14.

[15] Haqqani, A. M. Malik, B. A., Tahir, M., and Hussain, S. A 1987. Effect of seeding on yield and yield components of faba bean genotype. legumes. 10 (1); 11-12. 
[16] Hawtin G. C., Hebblethpiait P. D. (1983). Background and history of faba bean production. Pages 3-22 in The Faba Bean (Vicia faba L.) (Hebblethwaite, P. D., ed.). Buttenvorths, London, U.K.

[17] Herbek, J. H. and Bitzer, M. J. (1988). Soybean Production in Kentucky. Part III: Planting Practices and Double Cropping. Available Online: http://www.ca.uky.edu/agc/pubs/agr/agr130/agr130.htm.

[18] Karayel, D. and Özmerzi A. (2008). Evaluation of three Depth Control Components on Seed Placement Accuracy and Emergence for a Precision Planter, Applied Engineering in Agriculture. 24 (3): 271-276.

[19] Mohammad, R. A. (2011). Effects of Planting depth on germination and emergence of Field Bindweed (Convolvulus arvensis L.) Asian Journal of Agricultural Science. 3 (6): 459461.

[20] Naqvi H. K. (1984). Cultivation under the Sultans of Delhi c. 1206-1555. Indian J. History. Sci. 19: 329-340.

[21] Razia A. Tr. (2000). Nuskha Dar Fanni-Falahat: (The Art of Agriculture); (Persion Manuscript Compiled in the $17^{\text {Th }}$ Century by the Mughal Prince Dara Shikoh) (Agri-History Bulletin No. 3) MunshiramManoharlal Publishers Pvt Ltd. P. 98 .

[22] Siddig A., Ali M., Abdellatif Idris Y. (2015). Effect of Seed Size and Sowing Depth on Germination and Some Growth Parameters of Faba Bean (Viciafaba L.). Agricultural and Biological Sciences Journal. 1 (1): 1-5.

[23] Sikuku P. A., Netondo G. W., Onyango J. C. and Musyimi D. M. 2010: Effects of water deficit on physiology and morphology of three varieties of nerica rainfed rice (oryza sativa 1.) ARPN Journal of Agricultural and Biological Science, 5 (1): 23-28.

[24] Singh A. K., Bharat R. C., Chandra N. and Dimree S. (2010). Effect of Seed Size and Seeding Depth on Fava Bean (Vicia fava L.) Productivity. Environment \& Ecology 28 (3A): 17221727.
[25] Singh A. K, Bhat B. P, Sundaram P. K, Chndra N, Bharat R. C, Patel S. K. (2012). Faba bean (Vicia faba L.) phenology and performance in response to its seed size class and planting depth. Int. J. Agric. Stat. Sci. 8 (1): 97-109.

[26] Singh, A. K., Bharati, R. C., Manibhushan, N. C. and Pedpati, A. 2013. An assessment of faba bean (Vicia faba L.) current status and future prospect. African Journal of Agricultural Research 8 (55): 6634-6641.

[27] Tafere, M., Tadesse, D., \& Yigzaw, D. (2012). Participatory varietal selection of faba bean (Vicia faba L.) for yield and yield components in Dabat district, Ethiopia, Wudpecker. Journal of Agricultural Research, 1, 270-274.

[28] Thalji T. and Shalaldeh G., (2006). Effect of Planting Date on Faba bean (Vicia faba L.) Nodulation and Performance Under Semi- Arid Conditions. World Journal of Agricultural Sciences. 2 (4): 477-482.

[29] Umeoka, N. and Ogbonnaya, C. I. (2016). Effects of Seed Size and Sowing Depth on Seed Germination and Seedling Growth of Telfairia occidentalis (Hook F.). Int'l Journal of Advances in Chemical Engg., \& Biological Sciences (IJACEBS) Vol. 3 (2): 201-207.

[30] Yagmur M. and Kaydan D. (2009). The effects of different sowing depth on grain yield and some grain yield components in wheat (Triticum aestivum L.) cultivars under dryland conditions. African Journal of Biotechnology Vol. 8 (2): 196201.

[31] Yu YH, Cho DH, Lee IH, Ohh SH. 1990: Effect of seeding depth on severity of damping-off ginseng seedlings caused by Rhizoctonia solani. Korean J Ginseng Sci. 14: 432-436.

[32] Zohary D, Hopf M (2000). Domestication of plants in the old world: The origin and spread of cultivated plants in West Africa, Europe and the Nile valley. Oxford University Press New York USA. 